\title{
Dampak Program Bantuan Sepeda Motor Bercoolbox Terhadap Pendapatan Pedagang Ikan Keliling Di Provinsi Gorontalo
}

\author{
The Impact of Coolboxed Motorcycle Assistance Program to the Income of \\ Mobile Fish Trader in Gorontalo Province \\ Sitti Sabariah ${ }^{1}$, Mahludin Baruwadi ${ }^{1}$, Aziz Salam ${ }^{1}$ \\ ${ }^{1}$ Program Pascasarjana Universitas Negeri Gorontalo, Gorontalo, 906122, Indonesia \\ *Korespondensi: sitisabariapasca2016@gmail.com
}

\begin{abstract}
ABSTRAK
Tujuan penelitian ini adalah Mengetahui dampak program bantuan kendaraan bermotor coolbox pada peningkatan pendapatan pedagang ikan keliling di Provinsi Gorontalo, 2) Menganalisis tingkat motivasi berusaha pedagang ikan keliling setelah beroleh bantuan kendaraan bermotor coolbox di Provinsi Gorontalo dan 3) Menentukan strategi pengembangan program bantuan kendaraan bermotor coolbox di Provinsi Gorontalo. Penelitian ini dilakukan di Kota Gorontalo, Kabupaten Gorontalo dan Kabupaten Bone Bolango dari bulan Maret sampai dengan bulan Mei 2019 dengan jumlah sampel 68 orang pedagang ikan keliling penerima bantuan motor bercoolbox. Metode penelitian yang digunakan adalah metode survey. Analisis data yang digunakan yaitu Uji beda rata-rata (Uji-t), analisis deskriptif kualitatif berdasarkan teori Maslow mengacu pada skala Likert, dan analisis SWOT. Hasil penelitian menunjukkan bahwa bantuan sepeda motor bercoolbox kepada pedagang ikan keliling di Provinsi Gorontalo memberikan dampak positif. Hal ini terlihat dari peningkatan pendapatan dan peningkatan motivasi dari pedagang ikan keliling. Berdasarkan hasil analisis SWOT, diketahui bahwa kondisi internal Organisasi dalam hal ini Pemerintah Provinsi Gorontalo menggunakan strategi bertahan, mengendalikan kinerja internal. Strategi ini dipertahankan sambil terus berupaya membenahi diri dan masih perlu banyak dukungan serta pembinaan sehingga dari sektor perikanan bisa memberikan kontribusi yang signifikan dalam pembangunan wilayah dan strategi pengembangan program bantuan lainnya.
\end{abstract}

Kata kunci: Pendapatan, Motivasi, Uji Beda Rata-Rata, Sepeda motor ber-coolbox

\begin{abstract}
The objectives of this study are 1) To find out the impact of the coolbox motor vehicle assistance program on increasing the income of traveling fish traders in Gorontalo Province, 2) Analyzing the level of motivation to run a mobile fish trader after receiving coolbox motorized vehicle assistance in Gorontalo Province and 3) Determine the strategy for developing vehicle assistance programs motorized coolbox in Gorontalo Province. This research was conducted in Gorontalo City, Gorontalo Regency and Bone Bolango Regency from March to May 2019 with a total sample of 68 traveling fish traders who received motorbike box assistance. The research method used was a survey method. Analysis of the data used is the average difference test (t-test), a qualitative descriptive analysis based on Maslow's theory referring to a Likert scale, and a SWOT analysis. The results showed that motorbike box assistance to traveling fish traders in Gorontalo Province had a positive impact. This can be seen from the increase in income and increased motivation from itinerant fish traders. And based on the results of the SWOT analysis, that the internal conditions of the Organization in this case the Gorontalo Provincial Government used a survival strategy, controlling internal performance. This
\end{abstract}


strategy is maintained while continuing to improve itself and still needs a lot of support and guidance so that the fisheries sector can make a significant contribution in regional development and other assistance program development strategies.

Keywords: Income, Motivation, Average Difference Test, Coolbox Motorcycle

\section{PENDAHULUAN}

Tujuan pembangunan ekonomi adalah peningkatan pendapatan nasional dan pengurangan kemiskinan. Untuk mencapai tujuan tersebut perlu dikembangkan dan dikelola sumberdaya yang tersedia. Salah satu sumberdaya alam potensial yang dapat menunjang pembangunan tersebut adalah sumberdaya perikanan. Perikanan sebagai bagian integral dari sektor pertanian, dalam pembangunan ekonomi diarahkan pada peningkatan kontribusi subsector perikanan dalam penanggulangan berbagai permasalahan nasional di bidang pertanian (perikanan), antara lain meningkatkan devisa negara, menjamin tersedianya bahan pangan protein hewani, menciptakan lapangan kerja dan meningkatkan pendapatan nelayan/ petani ikan.

Sektor perikanan mempunyai peran dalam perekonomian yang bisa dilihat berdasarkan kontribusinya terhadap lapangan pekerjaan. Perikanan baik secara langsung maupun tidak langsung memainkan peranan penting bagi jutaan orang yang bergantung hidupnya pada sektor perikanan. Dalam rilis Badan $\mathrm{Pu}-$ sat Statistik Provinsi Gorontalo (2019) jumlah total tenaga kerja yang terlibat dalam sektor perikanan tangkap 19.585 jiwa dan budidaya 5.153 RTP. Di Indonesia sendiri sebagian besar masyarakat di daerah pesisir sangat bergantung hidupnya dari sektor perikanan sehingga tidaklah mengherankan jika sektor perikanan sering disebut sebagai employment of the last resort dimana tenaga kerja yang tidak terserap pada sektor lain akan mudah diserap oleh sektor perikanan.

Provinsi Gorontalo memiliki potensi sumberdaya kelautan dan perikanan yang berlimpah. Namun baru $50 \%$ potensi yang dikelola, setengahnya lagi belum termanfaatkan. Data Badan Pene- litian Kementrian Kelautan Republik Indonesia, kurang lebih baru 50\% potensi sumberdaya laut dan perikanan Gorontalo yang termanfaatkan. Kita masih mempunyai peluang kurang lebih 50\% untuk mengembangkan potensi perikanan dan kelautan sebagai ujung tombak pembangunan di provinsi Gorontalo (Dinas Kelautan dan Perikanan Provinsi Gorontalo, 2016).

Provinsi Gorontalo memiliki potensi perikanan dan kelautan yang cukup besar yang menjadi modal dasar pembangunan di Provinsi Gorontalo. Luas perairan yang mencapai $50.500 \mathrm{~km} 2$ yang terdiri dari luas wilayah laut teluk tomini, laut Sulawesi dan zona ekonomi eksklusif (ZEE) serta panjang garis pantai yang meliputi wilayah pantai Laut Sulawesi di utara dan Teluk Tomini di wilayah pantai selatan (Rencana Strategis 2012-2017 di Sektor Perikanan dan Kelautan Provinsi Gorontalo).

Kinerja sektor perikanan dan kelautan provinsi Gorontalo salah satunya adalah melalui program pengolahan dan pemasaran hasil perikanan. Dalam pelaksanaan program ini Dinas Perikanan dan Kelautan Provinsi Gorontalo, memfokuskan beberapa kegiatan yang menjadi indikator kinerja utama sektor Perikanan dan Kelautan. Kegiatan-kegiatan tersebut antara lain:

1) Peningkatan kelembagaan pelaku usaha perikanan, melalui pembinaan UMKM pengolahan dan pemasaran hasil perikanan serta melakukan bimbingan tekhnis produk olahan ikan bernilai tambah.

2) Pengembangan dan penyediaan sarana dan prasarana pengolahan serta pemasaran hasil perikanan, optimalisasi industri pengolahan pasca panen rumput laut melalui penguatan kelembagaan pelaku usaha rumput laut. 
Sedangkan untuk peningkatan jaminan mutu hasil perikanan yang akan dipasarkan, pemerintah Provinsi Gorontalo memberikan bantuan cumacuma motor roda dua bercoolbox bagi pedagang ikan yang masih menggunakan sepeda.

3) Kampanye peningkatan konsumsi ikan oleh kelembagaan Forum Peningkatan Konsumsi Ikan Nasional (FORIKAN) Daerah Provinsi Gorontalo bagi masyarakat, khusus bagi pelajar dan anak-anak sekolah.

Salah satu kelompok masyarakat yang memanfaatkan sumberdaya perikanan adalah pedagang ikan keliling. Dimana pedagang ikan keliling merupakan kelompok masyarakat yang melakukan aktivitas usaha dengan penghasilan bersumber dari kegiatan menjual ikan. Semakin banyak ikan yang terjual maka semakin besar pula pendapatan yang diterima dan pendapatan tersebut sebagian besar untuk keperluan konsumsi keluarga. Dengan demikian tingkat pemenuhan kebutuhan keluarga ditentukan oleh pendapatan yang diterimanya. Sumberdaya perikanan sebenarnya secara potensial dapat dimanfaatkan untuk meningkatkan taraf hidup dan kesejahteraan pedagang ikan keliling, namun pada kenyataannya masih banyak pedagang ikan belum dapat meningkatkan hasil penjualannya, sehingga tingkat pendapatan pedagang ikan tidak meningkat.

Pemerintah Provinsi Gorontalo sebagai penanggung jawab Pembangunan di daerahnya, berdasarkan pasal $18 \mathrm{UU}$ no 32/2004 tentang Pemerintahan Daerah menyebutkan bahwa Pemerintah Daerah berwenang untuk mengelola sumberdaya laut meliputi eksplorasi, eksploitasi, konservasi dan pengelolaan kekayaan laut. Dengan kewenangan tersebut dalam rangka meningkatkan ekonomi kerakyatan dan mendukung program Pemerintah pusat dalam hal ini Kementrian Kelautan Perikanan yaitu meningkatkan ekonomi Kerakyatan maka Pemerintah Provinsi Gorontalo dalam hal ini $\mathrm{Gu}$ bernur Gorontalo menggagas dan menu- angkan konsep kebijakan pengelolaan sektor kelautan dan perikanan berbasis pada pengelolaan perikanan dari hulu ke hilir. Melalui Dinas Perikanan dan Kelautan Provinsi Gorontalo, dimana lewat Program Pemasaran Hasil Perikanan sejak tahun 2012 hingga 2019 memberikan bantuan kepada masyarakat khususnya pedagang ikan keliling yang menggunakan sepeda di Provinsi Gorontalo, bantuan cuma-cuma berupa motor bercoolbox. Bantuan sarana pemasaran ini diberikan dengan sumber pendanaan dari Anggaran Pendapatan Belanja Daerah (APBD) Provinsi Gorontalo.

Setelah lima tahun pemberian bantuan ini tentunya perlu dievaluasi untuk mengetahui sejauh mana dampak bantuan sarana pemasaran hasil perikanan berupa motor bercoolbox terhadap peningkatan pendapatan pedagang ikan keliling yang menggunakan motor bercoolbox di Provinsi Gorontalo.

Berdasarkan pertimbangan tersebut di atas, maka tujuan penelitian ini adalah untuk mengetahui dampak program bantuan kendaraan bermotor coolbox pada peningkatan pendapatan pedagang ikan keliling, menganalisis tingkat motivasi berusaha pedagang ikan keliling setelah beroleh bantuan kendaraan bermotor coolbox dan menentukan strategi pengembangan program bantuan kenderaan bermotor coolbox

\section{METODE PENELITIAN}

Penelitian ini dilaksanakan di Provinsi Gorontalo yaitu Kota Gorontalo, Kabupaten Gorontalo dan Kabupaten Bone Bolango. Lokasi penelitian ditentukan secara purposive, dengan dasar pertimbangan daerah yang banyak terdapat pedagang ikan keliling penerima bantuan motor bercoolbox dari tahun 2012 - 2017. Untuk menetapkan jumlah sampel pada penelitian ini menggunakan perhitungan dengan rumus Slovin yaitu dari 213 pedagang ikan keliling di tiga lokasi tersebut maka diperoleh 68 sampel pedagang ikan keliling bermotor yang menggunakan coolbox secara acak sederhana. 
Untuk mengetahui dampak pemberian bantuan sepeda motor bercoolbox terhadap pendapatan pedagang ikan keliling di Provinsi Gorontalo maka penelitian ini dilakukan dengan analisis uji beda rata-rata (uji-t), yaitu membandingkan pendapatan pedagang ikan sebelum dan sesudah adanya bantuan sepeda motor bercoolbox. Menurut Sugiyono (2009) untuk menguji sampel berkorelasi/ berpasangan maka digunakan t-test sampel related dengan formulasi sebagai berikut:

$$
t=\frac{\bar{X}_{1}-\bar{X}_{2}}{\sqrt{\left(\frac{S_{1}{ }^{1}}{n^{1}}+\frac{S_{2}{ }^{2}}{n^{2}}\right)-2 r\left(\frac{S_{1}}{\sqrt{n_{1}}}\right)\left(\frac{S_{2}}{\sqrt{n_{2}}}\right)}}
$$

Dimana :

$\begin{array}{ll}\frac{\mathrm{T}}{\bar{X}_{1}} & =\text { nilai wilayah kritik ( } \mathrm{t} \text { hitung) } \\ \bar{X}_{2} & =\text { nilai rata-rata pendapatan sebelum adanya bantuan } \\ \mathrm{S}_{1} & =\text { nilai rata-rata pendapatan sesudah adanya bantuan } \\ \mathrm{S}_{2} & =\text { nilai simpangan baku pendapatan sebelum adanya bantuan } \\ \mathrm{S}_{1}{ }^{2} & =\text { nilai varians pendapatan sebelum adanya bantuan bantuan } \\ \mathrm{S}_{2}{ }^{2} & =\text { nilai varians pendapatan sesudah adanya bantuan } \\ \mathrm{r} & =\text { korelasi antara pendapatan sebelum dan sesudah adanya bantuan } \\ \mathrm{n}_{1} & =\text { jumlah sampel sebelum adanya bantuan } \\ \mathrm{n}_{2} & =\text { jumlah sampel sesudah adanya bantuan }\end{array}$

Untuk mengetahui tingkat motivasi diukur berdasarkan motif yang mendasari pedagang ikan dalam memanfaatkan bantuan sepeda motor bercoolbox, dengan menggunakan analisis deskriftif kualitatif dimana motivasi pedagang dikaji berdasarkan teori Maslow (2005) yaitu meliputi motif sosial, ekonomi, dan hiburan. Pengukuran menggunakan tes dengan pertanyaan yang dikembangkan dari motif-motif di atas. Masing-masing jawaban diberi skor (lima strata), mengacu pada skala Likert, yakni skala yang digunakan untuk mengukur sikap, pendapat, dan persepsi seseorang atau kelompok orang tentang fenomena sosial (Sugiyono, 2009). Data yang diperlukan berasal dari hasil jawaban atas pertanyaan yang diajukan kepada responden dalam bentuk kuesioner. Jawaban yang disediakan yaitu huruf berurutan dari huruf a sampai dengan huruf e memiliki nilai secara berurutan pula dari tinggi ke rendah dari skor 5 sampai dengan 1 yang didasarkan atas kepentingannya.
Interpretasi responden terhadap pemberian bantuan bagi pedagang ikan di Provinsi Gorontalo dapat dihitung dengan menggunakan persamaan sebagai berikut :

\section{Rumus Indeks (\%) = Total skor/Y x 100}

Selanjutnya untuk mengetahui strategi pengembangan bantuan adalah dengan menggunakan analisis deskriptif dengan menggunakan bantuan analisis SWOT untuk merumuskan strategi pengembangan bantuan (Nur'aini, 2016). Variabel-variabel yang dianalisis dalam penelitian ini adalah (1) Kekuatan (Strength); (2) Kelemahan (Weaknesses); (3) Peluang (Opportunities); Ancaman (Threats)

\section{HASIL DAN PEMBAHASAN Deskripsi Responden}

Umur pedagang ikan keliling penerima bantuan yang dijadikan sampel pada kelompok umur lebih dari 66 tahun 
berjumlah 8 pedagang atau sebesar 11,8 $\%$, jumlah pedagang ikan keliling pada kelompok umur 25-65 tahun adalah 60 pedagang ikan atau sebesar $88,2 \%$. Ini menunjukkan bahwa kebanyakan umur pedagang ikan keliling yang dijadikan sampel berada pada kelompok umur usia produktif.

Pendidikan pedagang ikan responden yang tidak sekolah sejumlah 28 orang atau sekitar $41,2 \%$, yang lulus SD - SMP adalah 35 orang atau 51,20\%, sedangkan yang SMA - Diploma sejumlah 5 orang atau $7,40 \%$. Hal ini menunjukkan bahwa tingkat pendidikan pedagang sampel sangat rendah. Rendahnya pendidikan inilah yang mendorong seseorang bekerja pada sektor perdagangan ikan, yaitu dimana yang diperlukan hanya keterampilan dan pengalaman berdagang.

Kondisi penjual ikan keliling yang menggunakan sepeda onthel dan sebelum mendapatkan bantuan adalah pendapatan yang tak seberapa, sebab jarak tempuh terbatas karena hanya menggunakan sepeda, waktu distribusi ikan ke masyarakat lambat, akibatnya warga menerima ikan yang tidak segar lagi dan fasilitas penampungan ikan pada sepeda tak dilengkapi kotak pendingin untuk dapat menjamin mutu ikan.

Sejak tahun 2012 Gubernur Gorontalo memberi bantuan kepada para pedagang ikan keliling di Gorontalo yang masih menggunakan sepeda dengan mengganti dengan sepeda motor ber kotak pendingin atau bercoolbox. Hingga tahun penelitian ini dibuat, sudah ada 456 sepeda motor berkotak pendingin yang dibagikan kepada para pedagang ikan keliling (Dinas Perikanan dan Kelautan Provinsi Gorontalo, 2018).

Menurut Haryanto (2011) pemenuhan kebutuhan manusia dapat terlaksana apabila keberadaan dan kontribusi orang lain terhubung dalam sebuah jalinan interaksi yang kompleks dan sistematis, ditandai dengan adanya permintaan barang dan jasa dari konsumen yang didistribusikan melalui transportasi. Transportasi merupakan alat terpenting dalam kelancaran system perekonomian.
Menurut Kadir (2006) transportasi berfungsi sebagai urat nadi kehidupan dan perkembangan ekonomi, sosial, politik dan mobilitas penduduk yang tumbuh bersamaan dan mengikuti perkembangan yang terjadi dalam berbagai bidang dan sektor.

\section{Pendapatan Pedagang Ikan Keliling}

Pendapatan harian dari 68 (enampuluh delapan) pedagang ikan keliling sebelum adanya pemberian bantuan berupa sepeda motor bercoolbox adalah bervariasi antara Rp. 15.000,(terendah) sampai Rp.75.000,- (tertinggi) dengan rata-rata pendapatan harian sebesar Rp.38.529. Setelah mendapatkan bantuan sepeda motor bercoolbox pendapatan harian pedagang ikan keliling meningkat pada kisaran antara Rp.37.500,- sampai dengan Rp.450.000,dengan rata-rata pendapatan harian sebesar Rp.85.000.-. Terjadi peningkatan rata-rata pendapatan harian sebesar Rp.46.508. Peningkatan pendapatan ini sebagai akibat dari adanya kualitas/mutu ikan lebih terjamin sehingga harga ikan naik dan wilayah jangkauan pemasaran ikan lebih jauh sehingga jumlah ikan yang terjual lebih banyak. Menurut Dahl \& Hammord (1977), pemasaran digambarkan sebagai urutan langkah-langkah atau tahapan-tahapan yang merupakan gerakan produksi dari satu titik produksi sampai titik konsumsi akhir. Kegunaan yang mampu diciptakan oleh kegiatan pemasaran meliputi penciptaan dan peningkatan mulai kegunaan tempat, waktu dan kepemilikan (Hanafiah \& Saefuddin, 1986). Pemasaran merupakan kegiatan yang penting dalam menjalankan usaha perikanan, karena pemasaran merupakan tindakan ekonomi yang berpengaruh terhadap naik-turunnya pendapatan nelayan. Hal ini perlu mendapat perhatian, karena dengan sistem pemasaran yang cepat dan tepat maka pedagang akan memperoleh pendapatan yang cepat dan jelas.

Menurut Andiny (2017), pedagang ikan sebagai pengusaha kecil informal akan selalu dihadapkan pada berbagai kendala keterbatasan, khususnya keterba- 
tasan skala usaha, manajemen usaha, modal, dan pemasaran. Umumnya permasalahan yang dihadapi pedagang ikan yaitu kualitas sumberdaya manusia masih rendah, keterbatasan pengetahuan, dan manajemen keuangan yang lemah.

Usaha penjualan ikan lazimnya dilakukan di berbagai daerah cenderung menjadi pekerjaan pokok bagi pedagang ikan sekaligus berperan sebagai kepala rumah tangga yang harus menghidupi keluarganya yang bekerja dibidang perikanan (Casrinah, 2003).

Data statistik perikanan dan kelautan tahun 2018 menunjukkan angka konsumsi ikan Provinsi Gorontalo meningkat dari tahun ke tahun, bahkan berada diatas rata-rata nasional. Pada tahun 2014, konsumsi ikan Provinsi Gorontalo sebesar 46,81 kg/kapita pertahun dan pada akhir tahun 2018 naik menajdi $58,10 \mathrm{~kg} / \mathrm{kapita}$ per tahun atau naik sebesar 24 persen (Dinas Perikanan dan Kelautan Provinsi Gorontalo, 2018).

Hasil penelitian Arnawa et al. (2016) menunjukkan bahwa dampak pemberian bantuan sarana perikanan tang-kap dapat meningkatkan pendapatan nelayan sebesar $2,6287 \%$ tidak berbeda nyata. Faktor-faktor yang berpengaruh nyata terhadap pendapatan nelayan adalah jenis perahu dan jumlah biaya yang dikeluarkan nelayan sedang faktorfaktor yang tidak berpengaruh nyata terhadap pendapatan nelayan adalah umur, pendidikan, jumlah alat tangkap, jenis alat tangkap, jarak tempuh dan lama melaut. Hasil penelitian Asih (2008) menunjukkan bahwa melalui bantuan kredit yang disalurkan terjadi peningkatan produktivitas, nelayan memperoleh tambahan manfaat yang cukup tinggi.

Angka-angka pendapatan tersebut kemudian dilanjutkan dengan pengujian secara statistik agar lebih menyakinkan tentang adanya perbedaan yang signifikan antara pendapatan pedagang ikan keliling sebelum dan setelah adanya pemberian bantuan sepeda motor bercoolbox, data pendapatan pedagang ikan keliling dapat dilihat pada Tabel 1.

Untuk menguji hipotesis yang diajukan dalam penelitian ini dilakukan dengan analisis uji beda rata-rata (uji-t) (Gambar 1), yaitu membandingkan pendapatan pedagang ikan sebelum dan sesudah adanya bantuan sepeda motor bercoolbox. Untuk menguji sampel berkolerasi/ berpasangan digunakan t-test sampel related dengan formulasi menurut Sugiyono (2009). Dengan nilai r, yaitu korelasi antara pendapatan sebelum dan sesudah adanya bantuan $=0,5024$ maka diperoleh nilai $t=-7,6571$. Harga $\mathrm{t}$ tersebut selanjutnya dibandingkan dengan harga $\mathrm{t}$ table dengan $\mathrm{dk}=\mathrm{n}_{1}+\mathrm{n}_{2}-2$ $=136-2=134$. Dengan $\mathrm{dk}=134$, dan bila taraf kesalahan ditetapkan sebesar $5 \%$, maka t table $=1,9778$.

Harga $t$ hitung lebih kecil dari $t$ table, $(-7,6571<-1,9778)$ sehingga Ho diterima dan $\mathrm{H}_{1}$ ditolak. Jadi terdapat perbedaan secara signifikan, nilai pendapatan pedagang ikan keliling sebelum diberi bantuan sepeda motor bercoolbox dan sesudah diberi bantuan.

Tabel 1. Nilai Pendapatan rata-rata berdasarkan pengujian statistik: Uji sampel Berpasangan

\begin{tabular}{llcc} 
No & Variabel Statistik & $\begin{array}{c}\text { Sebelum Menerima } \\
\text { Bantuan }\end{array}$ & $\begin{array}{c}\text { Setelah Menerima } \\
\text { Bantuan }\end{array}$ \\
\hline 1. & Jumlah Sampel & 68 & 68 \\
2. & Total Pendapatan & 2.620 .000 & 5.782 .500 \\
3. & Pendapatan rata-rata & 38.529 & 85.037 \\
4. & Simpangan Baku & 14.920 & 55.893 \\
5. & Varians & $222.618 .525,022$ & $3.123 .968 .777,44$ \\
\hline
\end{tabular}




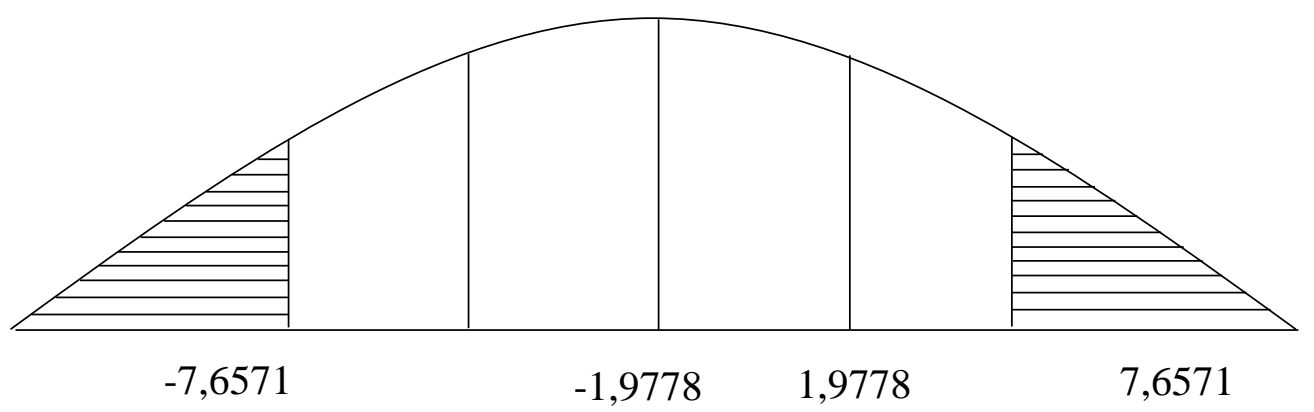

Gambar 1. Uji beda rata-rata dua pihak untuk membandingkan 68 pedagang ikan keliling sebelum dan setelah menerima bantuan

\section{Motivasi Berusaha Pedagang Ikan}

Motivasi merupakan faktor penggerak maupun dorongan serta interaksi seseorang dalam situasi yang dapat memicu timbulnya rasa semangat dan juga mampu merubah tingkah laku manusia atau individu untuk menuju pada hal yang lebih baik untuk dirinya sendiri.

Terdapat 68 orang pedagang ikan yang terdapat di Provinsi Gorontalo yang dijadikan responden untuk mengetahui apakah pemberian bantuan berupa kendaraan bermotor dengan menggunakan coolbox memberikan motivasi bagi para pedagang ikan keliling di Provinsi Gorontalo. Kuisioner yang diberikan untuk setiap orang terdiri dari 15 item pertanyaan. Hasil yang diperoleh dapat dilihat pada Tabel 2.

Jumlah skor tertinggi untuk pilihan jawaban SS yang diperoleh adalah 5100, sedangkan skor terendah untuk pilihan jawaban STS adalah 1020. Total skor penilaian responden yang telah diperoleh adalah sebesar 4501, sehingga diperoleh nilai indeks responden yang ada di Provinsi Gorontalo adalah sebesar $88.25 \%$, nilai ini kemudian di interpretasikan kedalam interval Indeks yang digunakan dalam skala Likert dibawah ini:

\section{Interval Indeks $=100 /$ jumlah skor likert}

Berdasarkan rumus tersebut di atas diperoleh interval sebesar 20 dengan menggunakan terendah $0 \%$ dan tertinggi
$100 \%$, sehingga kriteria interpretasi skor berdasarkan interval dapat ditunjukkan pada Tabel 3.

Berdasarkan nilai interval indeks yang diperoleh di Provinsi Gorontalo yaitu sebesar $88.25 \%$, maka dapat disimpulkan bahwa pedagang ikan di Provinsi Gorontalo dalam hal ini diwakili oleh Kota Gorontalo, Kabupaten Gorontalo dan Kabupaten Bone Bolango diinterpretasikan sangat setuju terhadap bantuan yang diberikan dalam meningkatkan motivasi pedagang ikan dalam meningkatkan kualitas dan kuantitas usaha yang dijalankan. Dahama dan Bhatnagar (1980) menjelaskan bahwa, motivasi merupakan sebuah argumen atau kombinasi antara kepentingan, perasaan, selera dan keinginan untuk meningkatkan tindakan yang mempunyai maksud dan menyadari akan keberadaannya. Koontz et al. (1980) mendefinisikan motivasi sebagai suatu pernyataan batin yang terwujud dengan adanya daya kekuatan untuk bertindak atau bergerak secara langsung melalui saluran perilaku yang mengarah pada tujuan atau sasaran. 
Tabel 2. Jumlah Responden dan Hasil Penilaian

\begin{tabular}{cccc}
\hline Pilihan Jawaban & $\begin{array}{c}\text { Jumlah } \\
\text { Responden }(\text { T) }\end{array}$ & $\begin{array}{c}\text { Penilaian } \\
(\text { Pn) }\end{array}$ & (T x Pn) \\
SS & 791 & 5 & 3595 \\
S & 219 & 4 & 876 \\
RR & 10 & 3 & 30 \\
TS & 0 & 2 & 0 \\
STS & 0 & 1 & 0 \\
Total & 1020 & & 4501 \\
\hline
\end{tabular}

Tabel 3. Presentase Nilai dalam Skala Likert

\begin{tabular}{cl}
\hline Interval Indeks & \multicolumn{1}{c}{ Interpretasi } \\
\hline $0 \%-19.99 \%$ & Sangat (Tidak Setuju, Buruk atau Kurang Sekali) \\
$20 \%-39.99 \%$ & Tidak Setuju atau Kurang Baik \\
$40 \%-59.99 \%$ & Cukup atau Netral \\
$60 \%-79.99 \%$ & Setuju, Baik atau Suka \\
$80 \%-100 \%$ & Sangat (Setuju, Baik, Suka) \\
\hline
\end{tabular}

\section{Strategi Pengembangan Program Bantuan}

Program pemberian bantuan sepeda motor bercoolbox di Provinsi Gorontalo bertujuan untuk meningkatkan kesejahteraan masyarakat khususnya pedagang ikan keliling di Provinsi Gorontalo. Implementasi program bantuan ini yang telah dilakukanan tidak terlepas dari kekurangan baik yang bersumber dari pelaksanaan program (dalam hal ini aparat pemerintah) maupun penerima program bantuan (pedagang ikan keliling). Namun demikian program bantuan tersebut telah berdampak positif dalam meningkatkan pendapatan pedagang ikan keliling penerima program bantuan. Oleh karena itu, program bantuan sepeda motor bercoolbox ini diharapkan dapat terus di implementasikan dengan berbagai perbaikan agar peningkatan pendapatan pedagang ikan keliling secara berkelanjutan.
Dalam rangka peningkatan pendapatan pedagang ikan keliling berkelanjutan, tentunya diperlukan strategi pengembangan program bantuan yang tepat. Untuk memilih strategi pengembangan program yang tepat digunakan analisis SWOT (Nur'aini, 2016). Analisis SWOT dilakukan untuk membandingkan faktor internal (kekuatan dan kelemahan) dengan faktor eksternal (peluang dan ancaman) terhadap usaha pemasaran ini. Analisis SWOT merupakan salah satu instrumen analisis strategik yang ampuh apabila digunakan dengan tepat. Keampuhan tersebut terletak pada kemampuan para penentu strategi untuk memaksimalkan peranan faktor kekuatan dan pemanfaatan peluang sehingga sekaligus berperan alat untuk meminimalisasi kelemahan yang terdapat dalam tubuh organisasi dan menekan dampak ancaman yang timbul dan harus dihadapi (Siagian, 1998). 
Tabel 4. Matriks SWOT beserta unsur-unsurnya

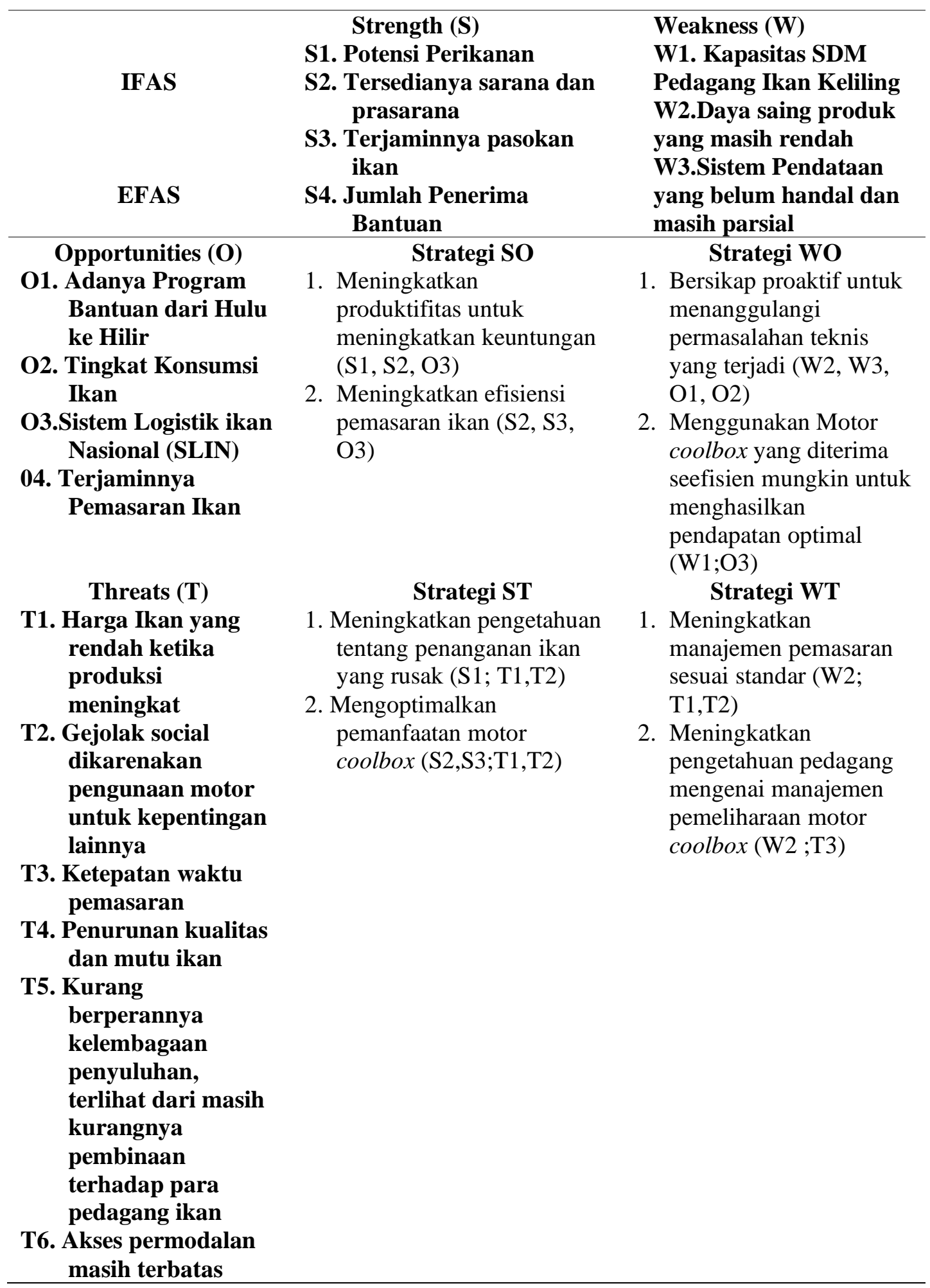


Berdasarkan hasil analisis SWOT, maka strategi pengembangan program bantuan kendaraan bercoolbox yaitu memberdayakan pedagang ikan keliling, melalui peningkatan Sumber Daya Manusia (SDM) dengan cara memberikan pelatihan, pembinaan dan sosialisasi tentang tekhnis penggunaan dan manfaat motor bercoolbox kepada pedagang ikan keliling sebelum mereka menerima bantuan motor bercoolbox.

\section{KESIMPULAN}

Berdasarkan analisis statistik uji beda rata-rata program bantuan sepeda motor bercoolbox memberikan dampak positif terhadap pedagang ikan keliling. Hal ini ditunjukkan oleh hasil analisis uji t yang menunjukkan terdapat perbedaan yang signifikan pendapatan pedagang ikan keliling sebelum dan sesudah program bantuan, dimana dengan program ini pendapatan pedagang ikan keliling lebih tinggi. Tingkat Motivasi berusaha pedagang ikan keliling di Provinsi Gorontalo setelah menerima bantuan meningkat sebesar $88,25 \%$, sedangkan strategi pengembangan program bantuan sepeda motor bercoolbox adalah dengan strategi bertahan, mengendalikan kinerja internal, berupaya membenahi diri dan masih perlu dukungan serta pembinaan sehingga sektor Perikanan memberikan kontribusi dalam pengembangan wilayah dan strategi pengembangan program bantuan lainnya.

\section{UCAPAN TERIMA KASIH}

Ucapan terima kasih terutama ditujukan kepada Program Pasca Sarjana Universitas Negeri Gorontalo (UNG), Dinas Kelautan dan Perikanan Provinsi Gorontalo serta semua pihak termasuk rekan-rekan angkatan 2016 yang telah membantu pelaksanaan penelitian ini.

\section{DAFTAR PUSTAKA}

Andiny, Puti dan Pipit Mandasari. 2017. "Analisis Pertumbuhan Ekonomi dan Kemiskinan Terhadap Ketimpangan di Provinsi Aceh".
Jurnal Penelitian Ekonomi Akuntansi (JENSI). No.2, Vol.1.

Asih, Dewi Nur. 2008. Dampak Kredit Terhadap Usaha Perikanan dan Ekonomi Rumahtangga Nelayan Tradisonal di Kabupaten Tojo Una-Una Provinsi Sulawesi Tengah. [Tesis]. Sekolah Pasca Sarjana Institut Pertanian Bogor, Bogor.

Arnawa, I Ketut, I B Purnama, dan Gede Mekse Korri Arisena. 2016. Dampak Bantuan Sarana Perikanan Tangkap Terhadap Peningkatan Pendapatan Nelayan di Kabupaten Gianyar Provinsi Bali. Jurnal Manajemen Agribisnis Vol. 4, No. 1, Mei 2016 ISSN: 2355-0759, Halaman 47.

BPS Provinsi Gorontalo. 2019. Data Perikanan dan Kelautan Provinsi Gorontalo.

Casrinah. 2003. Sistem Pemasaran HasilHasil Perikanan Laut di Tempat Pelelangan Ikan (TPI) Tanjungsari Kabupaten Pemalang. Skripsi S1.Fakultas Perikanan Universitas Pancasakti. Tegal.

Dahama O.P. and Bhatnagar O.P. 1980. Educational and Communication for Development, New Delhi: Oxford and Ibh Publishing Co.

Dinas Perikanan dan Kelautan Provinsi Gorontalo. 2018. Laporan Tahunan Program Pemberdayaan Masyarakat Bidang Perikanan dan Kelautan Provinsi Gorontalo. Hammond, J. And Dahl, Dale. C. 1977. Market and Price Analysis The Agricultural

Hanafiah dan Saefuddin. 1986. Tataniaga Hasil Perikanan. Edisi kedua. UI_Press. Jakarta. Industries. Mc. Graw-Hill, Inc, New York. Jakarta, 1984.

Hikmayani, Yayan dan Maharani Yulisti. 2015. Dampak Ekonomi Program Pengembangan Usaha Mina Pedesaan (PUMP) pada Usaha Pengolahan dan Pemasaran Hasil Perikanan". Jurnal Sosial Ekonomi Kelautan dan Perikanan Volume 10 No.2, Desember 2015. 
Koontz, Harold., Cyril O’Donnell, dan Heinz Weihrich. (1980). Manajemen. Jakarta : Erlangga.

Maslow, A.H. Frederick Herzberg, dan David McClelland. 2005. Job Satisfaction Theory.

Nur'aini, Fajar. 2016. Teknik Analisis SWOT. Yogyakarta: Buwas.

Renstra. 2012. Rencana Strategis Sektor Perikanan dan Kelautan Provinsi Gorontalo Tahun 2012-2017.

Siagian P, Sondang. 2000. Teori Motivasi dan Aplikasinya. Jakarta: Rineka Cipta.

Sugiyono. 2009. Metode Penelitian Kualitatif Kuantitatif dan R\&D. Bandung : Alfabeta 
